\title{
Adsorption of As(V) and As(III) from aqueous solution by lepidocrocite $(\gamma-$ $\mathrm{FeOOH}$ ) nanoparticle
}

- Nguyen Dinh Trung

- Truong Dong Phuong

Institute of Evironmental Research, Dalat University

(Received on $1^{\text {st }}$ October 2015, accepted on $2^{\text {th }}$ December 2016)

\section{ABSTRACT}

$\gamma$-FeOOH nanorods an adsorbent for $A s(V)$ and As(III) removal was prepared by a chemical co-precipitation method. The maximum adsorption capacities at pH6 for $A s(V)$ and As(III) were 63.75 and $88.99 \mathrm{mg} / \mathrm{g}$, respectively, higher than those of $\mathrm{Fe}_{2} \mathrm{O}_{3}, \mathrm{Fe}_{3} \mathrm{O}_{4} \ldots$ The adsorption data accorded with Freundlich isotherms. At the study $\mathrm{pH}$, for arsen, the adsorption equilibrium was gained after 90 min.
Kinetic data fitted well to the pseudo-secondorder reaction model. The adsorption of $\gamma$ $\mathrm{FeOOH}$ for As (V) and As(III) could be competed by some other ion such as sulfate, ammonium and chloride. The high adsorption capability and good performance on other aspects make the $\gamma$ $\mathrm{FeOOH}$ nanorod a promissing adsorbent for the removal of As (V) and As(III) from the groundwater.

Keywords: As (V), As(III), sorption, kinetic, $\gamma$-FeOOH nano

\section{INTRODUCTION}

Geogenic arsen (As) contamination in the groundwater is a major health problem that has been recognized in several regions of the world, especially in Bangladesh, West Bengal [1, 2], Vietnam [3-5], Cambodia [6, 7], Myanmar [8], and Mexico, where a large proportion of groundwater is contaminated with arsen at levels from 100 to $2000 \mu \mathrm{g} \mathrm{L}^{-1}$ [9].

In natural water, arsen is primarily present in inorganic forms and exists in two predominant species, arsenate $\mathrm{As}(\mathrm{V}) \quad\left(\mathrm{H}_{3} \mathrm{AsO}_{4}, \mathrm{H}_{2} \mathrm{AsO}_{4}{ }^{-}\right.$, $\left.\mathrm{HAsO}_{4}{ }^{2-}\right)$ and arsenic $\mathrm{As}(\mathrm{III})\left(\mathrm{H}_{3} \mathrm{AsO}_{3}, \mathrm{H}_{2} \mathrm{AsO}_{3}{ }^{-}\right.$, $\left.\mathrm{HAsO}_{3}{ }^{2-}\right)[10,11]$. As(III) is much more toxic and mobile than As(V). However, in the groundwater in nature, after exposure to air, the majority As(III) was transferred to As(V) [12].

Iron oxides indeed have been used for arsen removal [13-17] as well as, alumina [15], zeolite, titanium dioxide [18], and akaganeite [19]. In most cases, these low cost materials were used as filters $[10,20]$; while their modelling was attempted by the mechanism of surface complexation [21].

Among the possible treatment processes, the adsorption is considered to be less expensive than the membrane filtration, easier and safer to handle as compared to the contaminated sludge produced by precipitation, and more versatile than the ion exchange [22]. Adsorption process is considered to be one of the most promising technologies because the system can be simple to operate and low cost [23].

Among a variety of adsorbents for arsen removal, iron (hydro)oxides including amorphous hydrous ferric oxide, poorly crystalline hydrous ferric oxide (ferrihydrite) [24], goethite [25] and akaganeite [19] are well-known for their ability to removal inorganic arsen from aqueous system

Trang 270 
with low cost. Among these adsorbents the As(III) adsorption is normally less effective than the $\mathrm{As}(\mathrm{V})$ adsorption $[15,17,18]$. FeOOH has high adsorption capacity on arsenic [26], but it could not effectively remove both $\mathrm{As}(\mathrm{V})$ and As(III) simultaneously.

In the present study, a $\gamma$-FeOOH nanoparticle adsorbent was prepared by a chemical coprecipitation method, which was easy to operate and economic. The adsorbent was characterized and evaluated for its adsorption behavior of arsen. It exhibited high adsorption capacity for both $\mathrm{As}(\mathrm{V})$ and $\mathrm{As}(\mathrm{III})$.

\section{MATERIALS AND METHODS}

\section{Materials}

Stock solutions of $\mathrm{As}(\mathrm{V})$ and $\mathrm{As}(\mathrm{III}) 1000$ $\mathrm{mg} / \mathrm{L}$ (Merk). The working solutions were freshly prepared by diluting $\mathrm{Na}_{2} \mathrm{HAsO}_{4} \cdot 7 \mathrm{H} 2 \mathrm{O}$ and $\mathrm{As}_{2} \mathrm{O}_{3}$ with bidistilled water.

$\mathrm{HNO}_{3}(0.1-0.5 \mathrm{~N})$ and $\mathrm{NaOH}(0.1-0.5 \mathrm{~N})$ were used for adjusting the $\mathrm{pH}$ of the arsenic solution as necessary.

The ammonium (NH+) stock solution (500 $\left.\mathrm{mg} \mathrm{NH} 4^{+} / \mathrm{L}\right)$, the chloride $\left(\mathrm{Cl}^{-}\right)$stock solution $(500 \mathrm{mg} \mathrm{Cl} / \mathrm{L})$ and the sulfate $\left(\mathrm{SO}_{4}{ }^{2-}\right)$ stock solution $\left(500 \mathrm{mg} \quad \mathrm{SO}_{4}{ }^{2-} / \mathrm{L}\right)$ were prepared separately from ammonium chloride $\left(\mathrm{NH}_{4} \mathrm{Cl}\right)$ (Fisher, certified A.C.S.) and sodium sulfate $\left(\mathrm{Na}_{2} \mathrm{SO}_{4}\right)$ (Fisher, certified A.C.S.). Both solutions were used as the competing ions in some arsenic adsorption experiments.

Arsen in solutions was measured with Atomic Absorption Spectrometer (AA 7000 HVG1 Shimadzu).

All adsorption data were analysed by the Originlab 8.5.1 software.

\section{Methods}

\section{Preparation of $\gamma-\mathrm{FeOOH}$}

The $\gamma$-FeOOH adsorbent was prepared according to the following procedure [33]:
Dissolve $12 \mathrm{~g} \mathrm{FeCl}_{2} 4 \mathrm{H}_{2} \mathrm{O}$ in $300 \mathrm{~mL}$ distilled water with vigorous stirring. The beaker should be equipped with a glass electrode connected to a $\mathrm{pH}$ meter, a gas inlet connecting an air or oxygen cylinder and a dropping funnel containing $125 \mathrm{~mL} 1 \mathrm{M} \mathrm{NaOH}$. Adjust the $\mathrm{pH}$ of the system to $6.5-6.8$ by adding $\mathrm{NaOH}$ dropwise, then open the gas cylinder and aerate the air blowing rate $2 \mathrm{~L} / \mathrm{min}$. The initial greenish black precipitate becomes orange after $20 \mathrm{~min}$. Throughout the reaction, the $\mathrm{pH}$ of the suspension must be maintained at $6.5-6.8$, by adding $\mathrm{NaOH}$ from the dropping funnel as needed, centrifuge, wash and dry. The dried material was stored in a desiccator for use.

\section{$\gamma$-FeOOH nanoparticle}

Powder X-ray diffraction (XRD) was recorded on a Scintag-XDS-2000 diffractometer with $\mathrm{Cu} \mathrm{K} \alpha$ radiation $(\lambda=1.54059)$, scan rate at $2 \theta$ of $44.9^{\circ}$. Sample morphology was detected by scanning electron microscopy (SEM) on Hitachi H-7500.

\section{Batch sorption tests}

To determine the amount of adsorbed arsen (As(V) or As(III)) under the given conditions, approximately $0.1 \mathrm{~g}$ of adsorbent was weighed and placed in a 250-mL Erlenmeyer flask. One hundred millilitres of $\mathrm{As}(\mathrm{V})$ or $\mathrm{As}(\mathrm{III})$ solution was added into the flask. The concentration of the $\mathrm{As}(\mathrm{V})$ or As(III) solution ranged from 40 to 1000 $\mathrm{mg} / \mathrm{L}$ depending on the type of experiment. Ionic strength was not adjusted during the absorption. The flask was capped and shaken at $180 \mathrm{rpm}$ on an orbital shaker for $24 \mathrm{~h}$ to ensure the approximate equilibrium. All batch experiments were conducted at room temperature $\left(20{ }^{\circ} \mathrm{C}\right)$ unless stated otherwise. The $\mathrm{pH}$ was manually maintained at a designated value $\mathrm{pH}=6.0$ in such a way: $\mathrm{pH}$ was initially adjusted to a defined value with $0.01 \mathrm{~N} \mathrm{HNO}_{3}$ and $\mathrm{NaOH}$ and then measured and adjusted at an interval of $2 \mathrm{~h}$. After $24 \mathrm{~h}$ of the period reaction, all samples were 
centrifuged at $10.000 \mathrm{rpm}$ for 5 minutes and filtered through a $0.45-\mu \mathrm{m}$ membrane filter and the filtrate was analyzed for arsen. This procedure was used in all adsorption experiments for evaluating isotherms and interferences of competing ions, except for kinetic experiments. The quantity of adsorbed arsen was calculated by the difference of the initial and residual amounts of arsen in the solution divided by the weight of the adsorbent.

The amount of adsorbed metal was calculated from the following expression:

$$
\mathrm{q}=\mathrm{V}\left(\mathrm{C}_{\mathrm{i}}-\mathrm{C}_{\mathrm{e}}\right) / \mathrm{B}
$$

Where $\mathrm{q}$ is the metal uptake or sorption capacity of adsorbent (in $\mathrm{mg} / \mathrm{g}$ of adsorbent); $\mathrm{C}_{\mathrm{i}}$ and $\mathrm{C}_{\mathrm{e}}$ are the metal concentrations before and after adsorption, respectively, $\mathrm{B}$ is the mass of adsorbent used and $\mathrm{V}$ the solution volume used.

The pseudo-first-order adsorption and pseudo-second-order adsorption were used to test the adsorption kinetics data. The pseudo-firstorder rate expression of Lagergern is given as [27].

$$
\log \left(q_{e}-q_{t}\right)=\log q_{e}-\frac{k_{1}}{2.303} t
$$

or

$$
\ln \left(\mathrm{q}_{\mathrm{e}}-\mathrm{q}_{\mathrm{t}}\right)=\ln \mathrm{q}_{\mathrm{e}}-\mathrm{k}_{\mathrm{l}} \mathrm{t}
$$

Where $q_{e}$ and $q_{t}$ are the amount of arsenic adsorbed on adsorbent $(\mathrm{mg} / \mathrm{g})$ at equilibrium and time, and $k_{1}$ is the rate constant of pseudo-firstorder adsorption. The pseudo-second-order rate model is expressed as [28]:

$$
\frac{\mathrm{t}}{\mathrm{q}_{\mathrm{t}}}=\frac{1}{\mathrm{k}_{2} \mathrm{q}_{\mathrm{e}}^{2}}+\frac{1}{\mathrm{q}_{\mathrm{e}}} \mathrm{t}
$$

Where $\mathrm{k}_{2}$ is the constant of pseudo-secondorder rate $(\mathrm{g} / \mathrm{mg} \cdot \mathrm{min})$. The experimental data of $\mathrm{q}_{\mathrm{e}}, \mathrm{q}_{\mathrm{t}}$ and $\mathrm{k}_{2}$ can be determined from the slope and the intercept of the plot of $t / q_{t}$ against $t$.

\section{Studies of adsorption isotherm effect}

Experiments for studying the arsenic adsorption isotherm were conducted at $20^{\circ} \mathrm{C}$ and
$\mathrm{pH}=6.0$ by following the batch adsorption procedure. A series of different initial concentrations of As(V) or As(III) solutions (40$1000 \mathrm{mg} / \mathrm{L}$ ) at $\mathrm{pH}=6.0$ were used. For estimating the thermodynamic parameters of arsenic adsorption, the isotherm experiments were also conducted at $20{ }^{\circ} \mathrm{C}$.

\section{Studies of adsorption time effect}

The effects of time on arsenic adsorption were examined in a series of batch sorption experiments that used the same initial $\mathrm{As}(\mathrm{V})$ or As(III) concentration (100 $\mathrm{mg} / \mathrm{L})$ while maintaining the time at different values from 0 to 180 minutes.

\section{Adsorption kinetics studies}

Arsenic adsorption kinetics was evaluated at $20{ }^{\circ} \mathrm{C}$ and $\mathrm{pH}=6.0$. The initial $\mathrm{As}(\mathrm{V})$ or $\mathrm{As}(\mathrm{III})$ solution concentrations were $100 \mathrm{mg} \mathrm{As} / \mathrm{L}$. The kinetic experiments were conducted in a $250-\mathrm{mL}$ flask. The flask was shaken at $180 \mathrm{rpm}$. With this experimental setup the temperature of the solution inside the flask was well maintained at $20{ }^{\circ} \mathrm{C}, \mathrm{pH}$ was maintained at around $\mathrm{pH}=6.0$.

Arsenic adsorption with competing other ions

The interference of ammonium $\left(\mathrm{NH}_{4}{ }^{+}\right)$, chloride $\left(\mathrm{Cl}^{-}\right)$and sulfate $\left(\mathrm{SO}_{4}{ }^{2-}\right)$ on $\mathrm{As}(\mathrm{V})$ or As(III) adsorption was evaluated in batch experiments, respectively. The experimental method was similar to the batch adsorption method described previously. The difference was that the arsenic working solutions for these competing adsorption experiments were prepared with the separate addition of ammonium, chloride and sulfate solutions into the arsen solution. The initial addition of arsen was $100 \mathrm{mg} / \mathrm{g}$ adsorbent using an arsenic solution in $100 \mathrm{mg} \mathrm{As} / \mathrm{L}$ and the $\mathrm{pH}$ was maintained at approximately $\mathrm{pH}=6.0$. The concentrations of the competing anions used in the experiments were from 1 to $120 \mathrm{mg} / \mathrm{L}$ for ammonium, chloride and sulfate.

\section{Trang 272}




\section{RESULTS AND DISCUSSION}

\section{Characterization of $\gamma$-FeOOH adsorbent}

Lepidocrocite nanoparticles applied in this work consisted mainly of $\gamma-\mathrm{FeOOH}$, characterized by the basic reflection appearing at $2 \theta$ of $44.9^{\circ}$, as shown in the XRD diagram in (Fig. 1A) and (Fig. 1B)

This is evident from the XRD diagram in Fig. 1B, where the oxide appears in the form of lepidocrocite $(\gamma-\mathrm{FeOOH})$ and hematite $\left(\alpha-\mathrm{Fe}_{2} \mathrm{O}_{3}\right)$ (Fig. 1B). The $\alpha-\mathrm{Fe}_{2} \mathrm{O}_{3}$ percentage is very low. It is a by product of the synthesis process, and thus the corresponding peaks might be of $\gamma-\mathrm{FeOOH}$ (Fig. 1A).

A typical SEM image of the prepared sample was shown in Fig. 2, which reveals that the Lepidocrocite was a nanorod with the diameter of $20 \mathrm{~nm}$ and the length of $100 \mathrm{~nm}$.

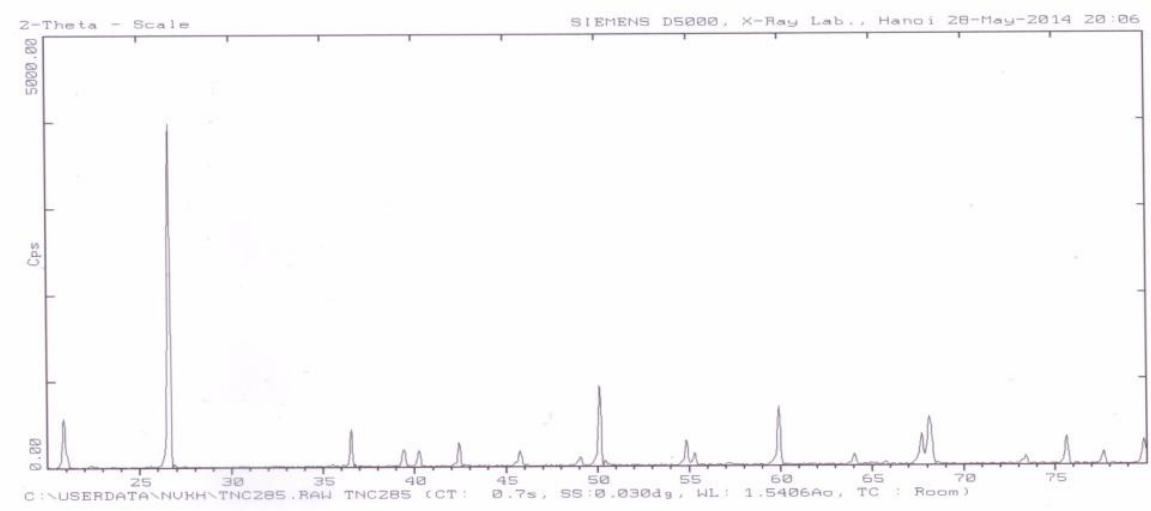

A.

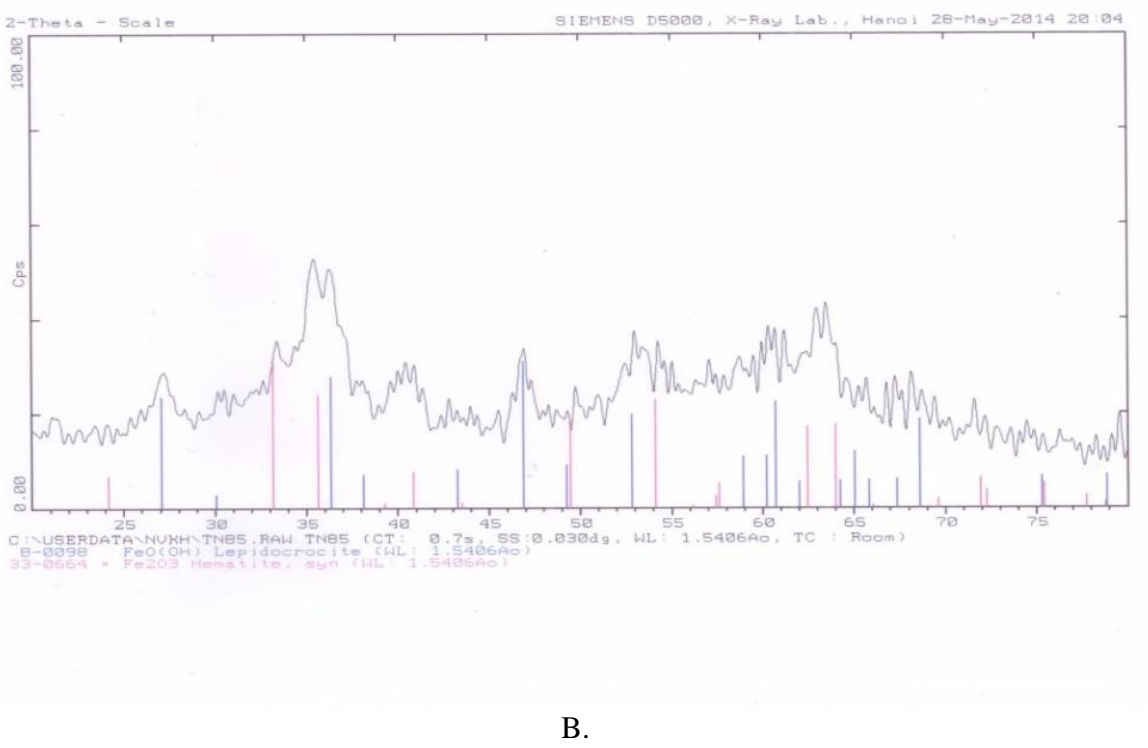

Figure 1. A) XRD patterns of $\gamma$-FeOOH synthesized samples; B) XRD patterns of synthesized samples 


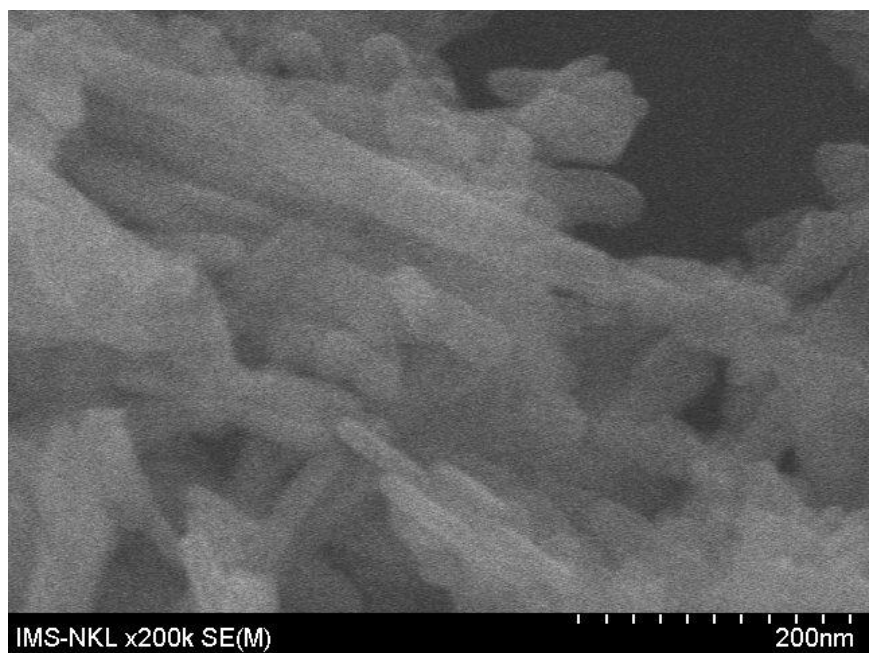

Figure 2. The SEM of $\gamma$-FeOOH samples

\section{Batch sorption tests}

\section{Adsorption isotherm of $\gamma$-FeOOH adsorbent}

The adsorbents were tested for adsorption of $\mathrm{As}(\mathrm{V})$ and $\mathrm{As}(\mathrm{III})$, as shown in Fig. 3A and Fig. 3B. The sorption capacity of As(III) by $\gamma$-FeOOH was higher than $\mathrm{As}(\mathrm{V})$ and the sorption capacity of $\gamma$-FeOOH was high compared to goethite (72.4 $\mathrm{mg} / \mathrm{g}$ ) [29].

The Langmuir expression was:

$$
q=\frac{q_{m} b C_{e}}{1+b C_{e}}
$$

Where $\mathrm{q}$ is the amount of $\mathrm{As}(\mathrm{V})$ adsorbed,

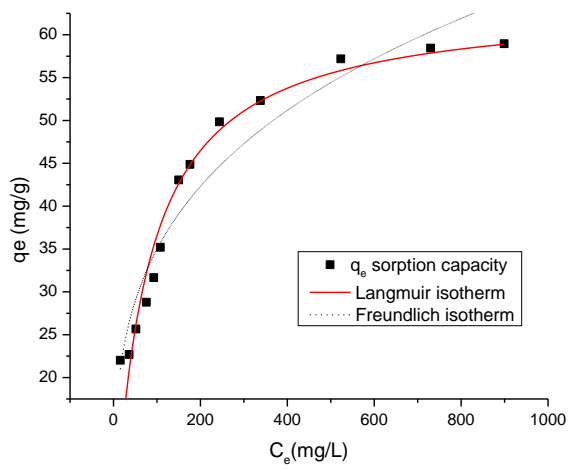

A. $\mathrm{mg} / \mathrm{g} ; \mathrm{q}_{\mathrm{m}}$ the maximum As(V) and As(III) uptake value corresponding to sites saturation, $\mathrm{mg} / \mathrm{g}$; $\mathrm{Ce}$ the equilibrium $\mathrm{As}(\mathrm{V})$ and $\mathrm{As}(\mathrm{III})$ concentration in solution, $\mathrm{mg} / \mathrm{L}$; and $\mathrm{b}$ is the ratio of adsorption/desorption rate. The result sorption of $\mathrm{As}(\mathrm{V})$ and $\mathrm{As}(\mathrm{III})$ by $\gamma$-FeOOH was shown in the Table 1.

The Freundlich expression was:

$$
q_{e}=K C_{e}^{1 / n}
$$

$\mathrm{K}=$ equilibrium constant indicative of adsorption capacity

$\mathrm{n}=$ adsorption equilibrium constant

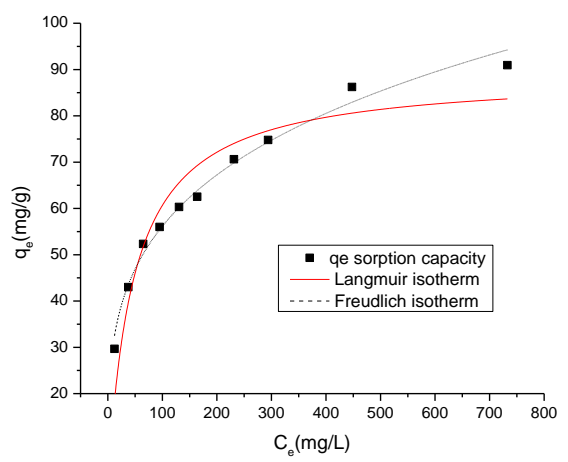

B.

Figure 3. A) Langmuir and Freundlich sorption isotherm of $\mathrm{As}(\mathrm{V})$ on $\gamma$-FeOOH; B) Langmuir and Freundlich sorption isotherm of $\mathrm{As}(\mathrm{III})$ on $\gamma-\mathrm{FeOOH}$ 
The adsorption isotherm of $\gamma$-FeOOH for $\mathrm{As}(\mathrm{V})$ and $\mathrm{As}(\mathrm{III})$ were presented in Fig. $3 \mathrm{~A}$ and Fig. 3B. In this study, both Langmuir and Freundlich isotherms were used to describe the adsorption isotherms. The adsorption constants obtained from the isotherms are listed in Table 1. The correlation coefficient $\left(\mathrm{R}^{2}\right)$ values of the Langmuir isotherms for $\mathrm{As}(\mathrm{V})$ was 0.92 and for As(III) was 0.89, while that of the Freundlich isotherms for $\mathrm{As}(\mathrm{V})$ was 0.93 and for $\mathrm{As}(\mathrm{III})$ was
0.98. High regression coefficients suggested that the Freundlich model was suitable for describing the adsorption behavior of $\mathrm{As}(\mathrm{V})$ and $\mathrm{As}(\mathrm{III})$ by $\gamma$-FeOOH.

The coefficient value $\left(\mathrm{R}^{2}\right)$ of the Freundlich isotherms for As(III) was higher than $\left(\mathrm{R}^{2}\right)$ value of Langmuir isotherms, in the sorption system due to a part of As(III) was transferred to As(V) [12].

Table 1. Langmuir and Freundlich isotherm parameters for $\mathrm{As}(\mathrm{V})$ and $\mathrm{As}(\mathrm{III})$ adsorption on $\gamma$-FeOOH adsorbent at $\mathrm{pH}=6.0$

\begin{tabular}{llll}
\hline Langmuir model & & & \\
\hline As species & $\mathrm{q}_{\mathrm{m}}(\mathrm{mg} / \mathrm{g})$ & $\mathrm{b}(\mathrm{L} / \mathrm{mg})$ & $\mathrm{R}^{2}$ \\
\hline $\mathrm{As}(\mathrm{V})$ & 63.75 & 0.90 & 0.92 \\
\hline $\mathrm{As}(\mathrm{III})$ & 88.99 & 1.01 & 0.89 \\
\hline Freundlich model & & & \\
\hline As species & $\mathrm{K}_{\mathrm{F}}(\mathrm{L} / \mathrm{mg})$ & $\mathrm{n}$ & $\mathrm{R}^{2}$ \\
\hline $\mathrm{As}(\mathrm{V})$ & 9.88 & 3.64 & 0.93 \\
\hline $\mathrm{As}(\mathrm{III})$ & 16.95 & 3.84 & 0.98 \\
\hline
\end{tabular}

Adsorption kinetics of $\mathrm{As}(\mathrm{V})$ by $\gamma$ - $\mathrm{FeOOH}$ adsorbent

The kinetics of adsorption is one of the important characteristics that define the adsorption efficiency. Hence, in the present study, the kinetics of arsenic adsorption was analyzed to understand the adsorption behavior of $\gamma$-FeOOH. Fig. 4 shows the adsorption data of $\mathrm{As}(\mathrm{V})$ and $\mathrm{As}(\mathrm{III})$ by $\gamma$-FeOOH at different time intervals. The adsorptions of both $\mathrm{As}(\mathrm{V})$ and As(III) by $\gamma$-FeOOH were found to be time dependent. The adsorption of $\mathrm{As}(\mathrm{V})$ and $\mathrm{As}(\mathrm{III})$ was rapid for the first $45 \mathrm{~min}$, when the removal rate reached $87 \%$ for $\mathrm{As}(\mathrm{V})$, and $76 \%$ for As(III), the removal reach was $97 \%$, after $90 \mathrm{~min}$ and the adsorption equilibrium was approached for both of $\mathrm{As}(\mathrm{V})$ and $\mathrm{As}(\mathrm{III})$. 


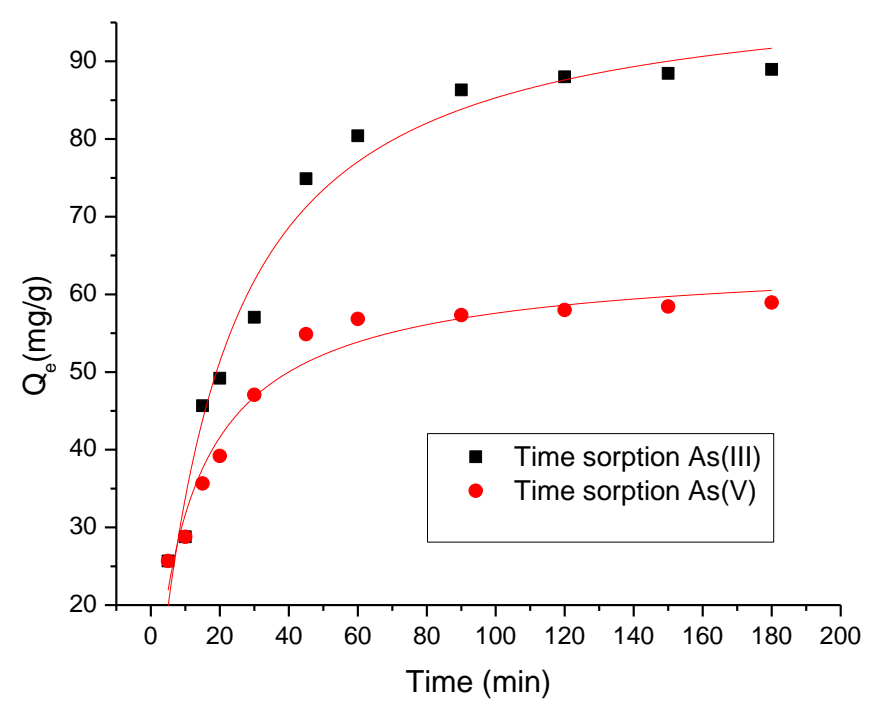

Figure 4. Time effect sorption of As (V) and As(III) by $\gamma$-FeOOH

Table 2, lists of the results of rate constant studies for $\mathrm{As}(\mathrm{V})$ and $\mathrm{As}(\mathrm{III})$ by pseudo-firstorder and pseudo-second-order. The values of correlation coefficient $\mathrm{R}^{2}$ for the pseudo-firstorder adsorption model are 0.97 for $\mathrm{As}(\mathrm{V})$ and 0.96 for As(III), (Fig. 5) and the adsorption capacities calculated by the model are different to those determined by experiments. The values of $\mathrm{R}^{2}$ for the pseudo-second-order are extremely high (>0.99) (Fig. 6), for both As(V) and As(III), the experimental data fitted the pseudo-secondorder model better than the pseudo-first-order model. Therefore, it can be concluded that the pseudo-second-order model is more suitable to describe the adsorption kinetics of arsenic on $\gamma$ $\mathrm{FeOOH}$. The rate of adsorption depends on the driving force and concentration gradient. In case of pseudo-first-order the rate is proportional to the concentration $(\Delta \mathrm{C})$ and in pseudo-secondorder, it is proportional to the square of concentration gradient $\left(\Delta C^{2}\right)$ which refers to both external as well as internal mass transfer [30]. This evidence shows that both the external and internal mass transfer is taken place. The As(V) ions existe as negative ions [31] in the experimental conditions. Therefore, $\operatorname{As}(\mathrm{V})$ ions may be easy to diffuse into the external and internal adsorption sites of adsorbent. So there was fast removal rate percentage of $\mathrm{As}(\mathrm{V})$ before $45 \mathrm{~min}$. This was not contradictory with the adsorption isotherms.

Trang 276 


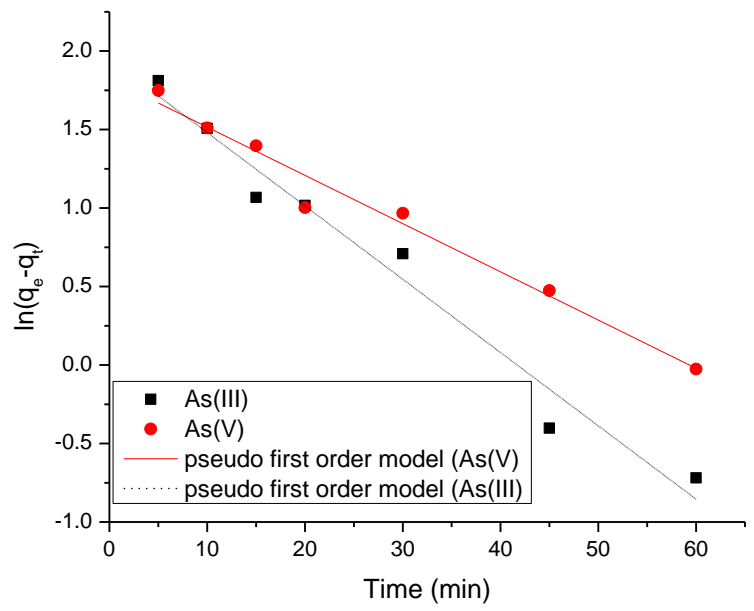

Figure 5. Pseudo-first-order model adsorption of $\mathrm{As}(\mathrm{V})$ and $\mathrm{As}(\mathrm{III})$ by $\gamma$-FeOOH

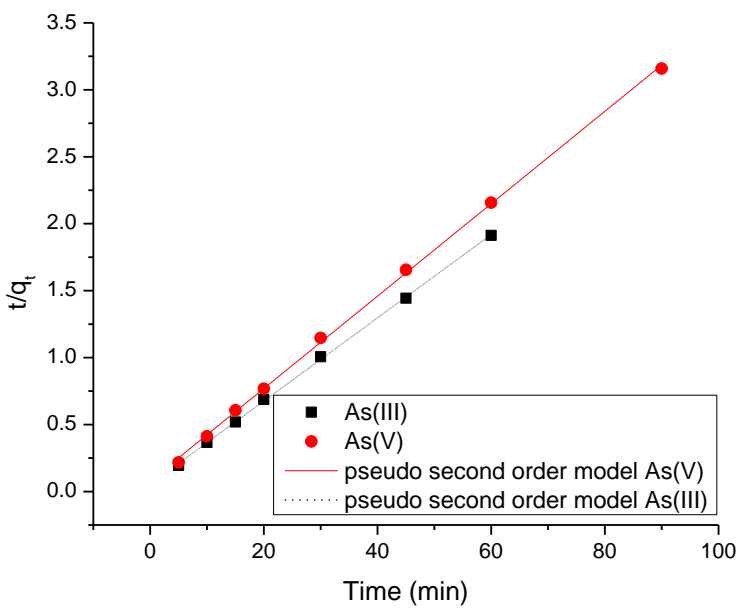

Figure 6. Pseudo-second-order model adsorption of $\mathrm{As}(\mathrm{V})$ and $\mathrm{As}(\mathrm{III})$ by $\gamma-\mathrm{FeOOH}$

Table 2. Composition of pseudo-first and pseudo-second-order adsorption rate constants

\begin{tabular}{|l|l|l|l|l|}
\hline \multicolumn{4}{|l|}{ Pseudo-first-order model } \\
\hline As species & $\mathrm{q}_{\text {e. exp }}(\mathrm{mg} / \mathrm{g})$ & $\mathrm{k}_{1}\left(\mathrm{~min}^{-1}\right)$ & $\mathrm{q}_{\mathrm{e} . \mathrm{cal}}(\mathrm{mg} / \mathrm{g})$ & $\mathrm{R}^{2}$ \\
\hline $\mathrm{As}(\mathrm{V})$ & 61.79 & 0.03 & 58.17 & 0.97 \\
\hline $\mathrm{As}(\mathrm{III})$ & 88.68 & 0.04 & 91.33 & 0.96 \\
\hline & Pseudo-second-order model & \multicolumn{2}{l|}{} \\
\hline As species & $\mathrm{q}_{\mathrm{e} \text { exp }}(\mathrm{mg} / \mathrm{g})$ & $\mathrm{k}_{2}(\mathrm{~g} / \mathrm{mg} \cdot \mathrm{min})$ & $\mathrm{qe} . \mathrm{cal}(\mathrm{mg} / \mathrm{g})$ & $\mathrm{R}^{2}$ \\
\hline As(V) & 61.79 & 0.02 & 63.75 & 0.99 \\
\hline As(III) & 88.68 & 0.02 & 88.93 & 0.99 \\
\hline
\end{tabular}




\section{Effect of other constituents on arsenic removal}

In natural groundwater or waste water several component might exist, which could compete with arsen for the available adsorption sites or interact with arsenic itself. In this study we select some ions $\left(\mathrm{Cl}^{-}, \mathrm{SO}_{4}{ }^{2-}\right.$, and $\left.\mathrm{NH}_{4}{ }^{+}\right)$to test the effect of co-existing constituents. Fig. 7A and Fig. 7B show the results of the effect of coexisting ions. $\mathrm{Cl}^{-}$had little or no effect on the arsen removal performance of the adsorbent. This is probably that the ions do not compete with the arsen ions. The oxyanions $\mathrm{SO}_{4}{ }^{2-}$ were selected to assess the effects of co-existing anions on $\mathrm{As}(\mathrm{V})$ and As(III) removal. At $\mathrm{pH}$ 6, the effects of those oxyanions increased the concentration level were illustrated in( Fig. 7A and 7B). The $\mathrm{NH}_{4}{ }^{+}$also had little effect on the arsenate removal performance of the adsorbent. This result is in agreement with previous studies [32].

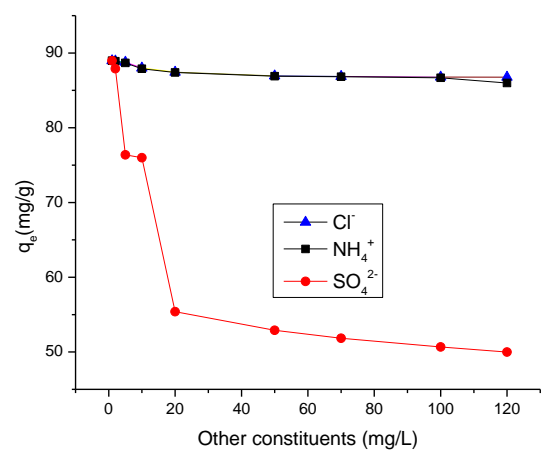

B.

Figure 7. A) Other constituents effect sorption of $\mathrm{As}(\mathrm{V})$ by $\gamma$-FeOOH; B) Other constituents effect sorption of $\mathrm{As}(\mathrm{III})$ by $\gamma$ - $\mathrm{FeOOH}$

\section{CONCLUSION}

A novel $\gamma$-FeOOH nanorod an effective adsorbent for $\mathrm{As}(\mathrm{V})$ and $\mathrm{As}(\mathrm{III})$ removal, has been prepared by a chemical co-precipitation method. At $\mathrm{pH} 6$ the maximum adsorption capacities for $\mathrm{As}(\mathrm{V})$ and $\mathrm{As}(\mathrm{III})$ were 63.75 and $88.99 \mathrm{mg} / \mathrm{g}$ respectively. At this $\mathrm{pH}$, for arsen, the removal rate reached $95 \%$ after $90 \mathrm{~min}$. In order to reveal useful informations for the sorption mechanism, typical adsorption isotherms
(Langmuir and Freundlich) were determined and X-ray photoelectron spectroscopy analysis was used. The mechanism of the removal seemed rather to be a chemisorption, based on the kinetics sorption.

The sulfate was a competitor with arsenic for adsorptive sites on the adsorbent. These results indicated that the $\gamma$-FeOOH nanorod was an attractive adsorbent for the removal of arsenic from aqueous solutions. 


\section{Hấp thu $\mathrm{As}(\mathrm{V})$ và $\mathrm{As}(\mathrm{III})$ từ dung dịch nước bởi lepidocrocite $(\gamma-\mathrm{FeOOH})$ dạng nano}

\section{- Nguyễn Đình Trung \\ - Trương Đông Phương \\ Viện nghiên cứu Môi trường, Trường Đại học Đà Lạt \\ TÓM TẮT}

$\gamma$-FeOOH dạng nano dùng làm vật liệu hấp phu $A s(V)$ và As(III) được điều chế bằng phuoong pháp đồng kết tủa. Tại $p H=6,0$, dung luợng hấp phu cưc đại của vật liệu đối với $A s(V)$ và As(III) lần luoọt là 63,75 và $88,99 \mathrm{mg} / \mathrm{g}$, cao hon so với một số vật liệu làm chất hấp phu arsen nhu $\mathrm{Fe}_{2} \mathrm{O}_{3}, \mathrm{Fe}_{3} \mathrm{O}_{4}$. Mô hình hấp phu đẳng nhiệt Freundlich mô tả quá trình hấp phu As(v) và As(III) bởi $\gamma$-FeOOH, thời gian đạt cân bằng hấp phu là 90 phút. Động học hấp phu tuân theo

phuơng trình động học hấp phu bậc 2. Quá trình hấp phu của $\gamma$-FeOOH đối vói $A s(V)$ và $A s(I I I)$ có thể bị cạnh tranh bởi các ion khác nhu sulfate, ammonium và chloride (theo thư tư giảm dần). Vật liệu $\gamma$-FeOOH dạng nano, với dung luợng hấp phu $A s(V)$ và $A s(I I I)$ cục đại, việc điều chế dễ dàng với giá thành thấp, là chất hấp phu đầy tiềm năng trong việc xủ lý arsen trong nuớc ngầm.

Tù khóa: $A s(V)$; As(III), hấp phụ, động học hấp phu, $\gamma$-FeOOH nano

\section{REFERENCES}

[1]. R. Nickson, J. McArthur, W. Burgess, K.M. Ahmed, P. Ravenscroft, M. Rahman, Arsenic poisoning of Bangladesh groundwater, Nature, 395, 338-339 (1998).

[2]. U. Chowdhury, B. Biswas, T. Chowdhury, G. Samanta, G. Basu, C. Chanda, K. Lodh, S. Mukherjee, S. Roy, S. Kabir, Q. Quamruzzaman, D. Chakraborti, Groundwater arsenic contamination in Bangladesh and West Bengal, India, Environmental Health Perspectives, 108, 393-397 (2000).

[3]. M. Berg, H.C. Tran, T.C. Nguyen, H.V. Pham, R. Schertenleib, W. Giger, Arsenic contamination of groundwater and drinking water in Vietnam: a human health threat, Environmental Science \& Technology, 35, 2621-2626 (2001).

[4]. M. Berg, H.C. Tran, T.C. Nguyen, M.V. Pham, Magnitude of arsenic pollution in the Mekong and Red River DeltasCambodia and Vietnam, Science of the Total Environment, 372, 413-425 (2006).

[5]. M. Berg, P.T.K. Trang, C. Stengel, J. Buschmann, P.H. Viet, W. Giger, D. Stüben, Hydrological and sedimentary controls leading to arsenic Hanoi Area, Vietnam: The impact of iron-arsenic ratios, peat, river bank deposits, and excessive groundwater abstraction, Chemical Geology, 249, 91-112 (2008).

[6]. D.A. Polya, A.G. Gault, N. Diebe, P. Feldman, J.W. Rosenboom, E. Gilligan, D. Fredericks, A.H. Milton, M. Sampson, H.A.L. Rowland, P.R. Lythgoe, J.C. Jones, C. Middleton, D.A. Cooke, Arsenic hazard in shallow Cambodian groundwaters, Mineralogical Magazine, 69, 807-823, (2005). 
[7]. J. Buschmann, M. Berg, C. Stengel, L. Winkel, M.K. Sampson, P.T.K. Trang, P.H. Viet, Contamination of drinking water resources in the Mekong delta floodplains: arsenic and other trace metals pose serious health risks to population, Environment International, 34, 756-764 (2008).

[8]. L. Winkel, M. Berg, M. Amini, S.J. Hug, C.A. Johnson, Predicting groundwater arsenic contamination in Southeast Asia from surface parameters, Nature Geoscience, 1, 536-542 (2008).

[9]. P.L. Smedley, D.G. Kinniburgh, A review of the source, behaviour and distribution of arsenic in natural waters, Applied Geochemistry, 17, 5, 517-568 (2002).

[10]. J.F. Ferguson, J. Gavis, A review of the arsenic cycle in natural waters, Water Research, 6, 11, 1259-1274 (1972).

[11]. B.A. Manning, Hunt, M.L. C. Amrhein, J.A. Yarmoff, Arsenic(III) and $\operatorname{arsenic}(\mathrm{V})$ reactions with zerovalent iron corrosion products, Environmental Science \& Technology, 36, 24, 5455-5461 (2002).

[12]. W.R. Cullen, K.J. Reimer, Arsenic speciation in the environment, Chemical Reviews, 89, 4, 713-764 (1989).

[13]. S.R. Kanel, B. Charlet, L. Choi, Removal of As(III) from groundwater by nanoscale zerovalent iron, Environmental Science \& Technology, 39, 1291-1298 (1989).

[14]. S.R. Kanel, J.M. Greneche, H. Choi, $\mathrm{As}(\mathrm{V})$ removal from ground water using nanoscale zerovalent iron as a colloidal reactive barrier material, Environmental Science \& Technology, 40, 2040-2045, (2006).

[15]. B. Dousova, T. Grygar, A. Martaus, L. Fuitova, D. Kolousek, V. Machovi, Adsorption of $\mathrm{As}(\mathrm{V})$ on aluminosilicates treated with $\mathrm{Fe}(\mathrm{II})$ nanoparticles, Journal of Colloid and Interface Science, 302, 424-431 (2006).

[16]. K. Hristovski, A. Baumgardener, P. Westerhoff, Selecting metal oxide nanomaterials for arsenic removal in fixed bed columns: From nanoparticles to aggregated nanoparticles media, Journal of Hazardous Materials, 147, 265-274 (2007).

[17]. J.T. Mayo, C. Yavuz, S. Yean, L. Cong, H. Shipley, W. Yu, J. Falkner, A. Kan, M. Tomson, V.L. Colvin, The effect of nanocrystalline magnetite size on arsenic removal, Science and Technology of Advanced Materials, 8, 71-75 (2007).

[18]. M.E. Pena, G.P. Koratis, M. Patel, L. Lippincott, X. Meng, Adsorption of As(V) and $\mathrm{As}(\mathrm{III})$ by nanocrystalline titanium dioxide, Water Research, 39, 2327-2337 (2005).

[19]. E.A. Deliyanni, L.K. Nalbandian, A. Matis, Adsorptive removal of arsenites by a nanocrystalline hybrid surfactantakaganeite sorbent, Journal of Colloid and Interface Science, 302, 458-466 (2006).

[20]. O.X. Leupin, S.J. Hug, A.B.M. Badruzzaman, Arsenic removal from Bangladesh tube well water with filter columns containing zerovalent iron filings and sand, Environmental Science \& Technology, 39, 8032-8037 (2005).

[21]. M. Lehmann, A.I. Zouboulis, K.A. Matis, A. Grohmann, Adsorption of arsenic oxyanions from aqueous solution on goethite: a study of process modelling, Microchimica Acta, 151, 269-275 (2005).

[22]. X. Guo, F. Chen, Removal of arsenic by bead cellulose loaded with iron oxyhydroxide from groundwater, Environmental Science \& Technology, 39, 17, 6808-6818 (2005).

[23]. M. Jang, S.H. Min, T.H. Kim, J.K. Park, Removal of arsenite and arsenate using

Trang 280 
hydrous ferric oxide incorporated into naturally occurring porous diatomite, Environmental Science \& Technology, 40, 5, 1636-1643 (2006)

[24]. Y. Jia, G.P. Demopoulos, Adsorption of arsenate onto ferrihydrite from aqueous solution: influence of media (Sulfate vs Nitrate), added gypsum, and $\mathrm{pH}$ alteration, Environmental Science \& Technology, 39, 24, 9523-9527 (2006).

[25]. S. Fendorf, M.J. Eick, P. Grossl, D.L. Sparks, Arsenate and chromate retention mechanisms on goethite. 1. Surface structure, Environmental Science \& Technology, 31, 2, 315-320 (1997).

[26]. X. Guo, F. Chen, Removal of arsenic by bead cellulose loaded with iron oxyhydroxide from groundwater, Environmental Science \& Technology, 39, 17, 6808-6818 (2005).

[27]. M.S. Chiou, H.Y. Li, Adsorption behavior of reactive dye in aqueous solution on chemical cross-linked chitosan beads, Chemosphere, 50, 8, 1095-1105 (2003).

[28]. Y.S. Ho, G. McKay, Pseudo-second order model for sorption processes, Process Biochemistry, 34, 5, 451-465 (1999).
[29]. K.A. Matis, A.I. Zouboulis, D. Zamboulis, A.V. Valtadorou, Sorption of As(V) by goethite particles and study of their flocculation, Water, Air \& Soil Pollution, 111, 297-316 (1999).

[30]. A.K. Jain, V.K. Gupta, A. Bhatnagar, Suhas, Utilization of industrial waste products as adsorbents for the removal of dyes, Journal of Hazardous Materials, 101, 1, 31-42 (2003).

[31]. Y. Kim, C. Kim, I. Choi, S. Rengaraj, J. $\mathrm{Yi}$, Arsenic removal using mesoporous alumina prepared via a templating method, Environmental Science \& Technology, 38, 3, 924-931 (2004).

[32]. G. Zhang, J. Qu, H. Liu, R. Liu, R. Wu, Preparation and evaluation of a novel FeMn binary oxide adsorbent for effective arsenite removal, Water Research, 41, 9, 1921-1928 (2007).

[33]. U. Schwertmann, H. Fechter, The formation of green rust and its transformation to lepidocrocite, Clay Min, 29, 87-92 (1994). 